\title{
Effect of Moisture Content on Some Physical Properties of Three Varieties of Kodo (Paspalum scrobiculatum L.) Millet
}

\author{
Shalini Chaturvedi ${ }^{1}$, Atul Kumar Shrivastava ${ }^{1 *}$, R. Shiv Ramakrishnan ${ }^{2}$, \\ Ganesh Kumar Koutu ${ }^{2}$ and Sanjay Singh ${ }^{2}$ \\ ${ }^{1}$ Department of Farm Machinery and Power Engineering, College of Agricultural \\ Engineering, ${ }^{2}$ College of Agriculture, JNKVV, Jabalpur. M.P., India \\ *Corresponding author
}

\section{A B S T R A C T}

\section{Keywords}

Kodo millet,

Moisture content, Physical property,

Improved variety

\section{Article Info}

Accepted:

xx August 2020

Available Online:

xx September 2020
Kodo millet is one of the important millet crop grown mainly in Madhya Pradesh, India. Kodo is high in nutrition value with protein, fat and carbohydrate. The physical property of Kodo determine with three variety JNK-(101), JNK-(364) and Niwas-(1) at three moisture content $7 \%, 11 \%$ and $12.6 \%(\mathrm{db})$. It was found that L,B,T in JNK-(101) ranging from 2.38 to $2.68 \mathrm{~mm}, 1.43$ to $2 \mathrm{~mm}$, and 1.01 to $1.34 \mathrm{~mm}$. Similarly in JNK-(364 ) L,B,T range from 2.27 to $2.72 \mathrm{~mm}, 1.34$ to $1.75 \mathrm{~mm}$ and 0.96 to $1.30 \mathrm{~mm}$, in Niwas-(1)L,B,T range from 2.44 to $2.95 \mathrm{~mm}, 1.78$ to $2.32 \mathrm{~mm}$ and 1.32 to $1.70 \mathrm{~mm}$. The size of Kodo in all three variety ranges from 1.49 to $1.91 \mathrm{~mm}, 1.43$ to $1.82 \mathrm{~mm}$ and 1.76 to $2.24 \mathrm{~mm}$ respectively. Sphericity increases in all three variety from 0.63 to $0.72 \mathrm{~mm}, 0.61$ to $0.67 \mathrm{~mm}$ and 0.72 to $0.76 \mathrm{~mm}$. The bulk density, true density and porosity in JNK-(101) ranges from 681 to $667.67 \mathrm{~kg} / \mathrm{m}^{3}, 1228.50$ to $1202.67 \mathrm{~kg} / \mathrm{m}^{3}$ and 44.57 to $43.74 \%$. Similarly in variety JNK(364) the value ranged from 684.33 to $674.33 \mathrm{~kg} / \mathrm{m}^{3}, 1228.80$ to $1201.33 \mathrm{~kg} / \mathrm{m}^{3}$ and 44.31 to $43.87 \%$. this trend also followed in Niwas-1 varied from 686.07 to $671.67 \mathrm{~kg} / \mathrm{m}^{3}$, 1227.90 to $1203 \mathrm{~kg} / \mathrm{m}^{3}$ and 44.13 to $43.84 \%$ respectively. The angle of repose in JNK(101) 25.28 to 26.07 , JNK-(364) 25.26 to 26.04 and niwas-(1) 25.39 to 26.07 respectively. The physical property are used to determine the appropriate dimension for the designing of machine.

\section{Introduction}

The word "Millets" is used to represent many small-grained cereals. Millets crops comprise of pearl millets, sorghum, finger millet \& small millets namely foxtail millets (Kagani), Kodo millets (Kodo), proso millets (Cheena), barnyard millets (Sawan) and little millets (Kutki). Millets are one of the oldest cultivated food grains known to humans and have been a staple food in Northern Africa for thousand years and was a staple food in China and India prior to popularity of fine cereals like rice and wheat. These crops have a long history of cultivation of more than 5000 years and grown in many states. The area of small millets in India recorded 682.33 thousand ha, with production of 429.9 thousand and yield 
$630.00 \mathrm{Kg} /$ ha. Madhya Pradesh covers 33.4percent (227.7 thousand ha) of area and contributes 26.6 percent (114.5 thousand) of production with the average yield of only 503 $\mathrm{Kg} / \mathrm{ha}$ small millets in the country (Directorate of Economics and Statistics (2015).

Kodo grains contain protein $(8.35 \%)$, fat $(1.45 \%)$, carbohydrates $(65.65 \%)$ and ash $(2.95 \%)$. It may be considers as Nutri-cereal little millet exhibit diversified use as food, feed and fodder. The grain compares well with other cereals. It is a fair source of protein (7070 to $16.50 \%)$, fat (2.45 to $9.04 \%$ ), carbohydrates (62.50 to $76.30 \%)$, an excellent source of dietary fibre (15.90 to $18.10 \%$ ) with good amount of soluble (3.15 to 5.70\%) and insoluble (10.20 to $14.95 \%)$ fractions (Kulkarni et al., 1992, Hadimani and Malleshi, 1993 and Itagi, 2003).

Designing of machinery requires thorough an understanding of essential engineering properties of agricultural material. Such basic information is of great importance for not only to engineers but also to food scientist and processor and other scientists who may exploit these properties and find new uses (Mohsenin, 1986). Knowledge of physical properties and their dependence on the moisture content is useful for the design and development of machine. These properties are used in analyzing and determining the efficiency of the machine and operation or process as well as determine quality or studying the behaviour of the product during testing of the machine. Basic information on these engineering properties is of great importance and help engineers towards efficient process and machine development. (Kumar et al., 2016) studied engineering properties of variety Indira Kode-1 in the moisture range from 8.19 to 12.71 per cent (db) and observed that the length, width and thickness of Kodo increased with increasing moisture content and also observed that with the increased moisture content the length breadth ratio of Kodo decreased. The size and sphericity of Kodo increased with the increase of moisture content, surface area and volume of Kodo grain increased with the increased in moisture content. The values of bulk density but true density and porosity was increased with increase in moisture content. The angle of repose was increased with an increase of moisture content.

\section{Materials and Methods}

The engineering properties of Kodo millet with three variety of Kodo such as JNK-101, JNK-364 and Niwas-1. Different properties of Kodo such as moisture content, length, width, thickness, size, sphericity, angle of repose, bulk density, true density and porosity were determined by using standard techniques. To determine the effect of moisture content on different physical properties of Kodo the moisture content was determined.

\section{Moisture content}

It is the ratio of weight of moisture to weight of dry product. It is expressed in percentage.

Moisture content $(\mathrm{db}) \%=$

weig $\square t$ of moisture

$\frac{\text { weig } \square t \text { of dry matter }}{x} \times 100$ ...........1

\section{Length, width and thickness (LBT)}

For the measurement of seed length (L), width (W) and thickness (T), randomly 100 grains from each variety were selected for determination of $\mathrm{L}, \mathrm{W}$ and $\mathrm{T}$ by using vernier calliper with a least count of $0.01 \mathrm{~mm}$. Size of the seeds was calculated with the following formula proposed by [2].

$\mathrm{S}_{\mathrm{Z}}=(\mathrm{L} \times \mathrm{W} \times \mathrm{T})^{1 / 3} \ldots(2)$ 


\section{Sphericity $(\varphi)$}

Sphericity is defined as the ratio of the size of grains to the length of the grain. The sphericity is expressed in per cent. [3].

$\emptyset=\frac{(L X B X T)^{1 / 1 / s}}{L} \ldots(3)$

\section{Bulk density $\left(B_{d}\right)$}

Bulk density of Kodo grains was determined by taking the weight of Kodo in fixed volume [4].

$\mathrm{B}_{\mathrm{d}}=\frac{W}{V}$

\section{True density (Td)}

True density is defined as the ratio of the mass of grain to the solid volume occupied. It is determined using liquid displacement technique [5].

$\mathrm{T}_{\mathrm{d}}=\frac{M}{s} \ldots$

\section{$\operatorname{Porosity}(\varepsilon)$}

Porosity was calculated as the ratio of the difference in the grain and bulk densities to grain density and expressed in percentage [6].

(c) $\%=1-\frac{B_{d d}}{T_{d d}} \ldots(6)$

\section{Angle of repose}

A cylinder was filled up to top with sample and inverted on a plane (paper) surface. The paper was taken out gradually and cylinder was raised vertically, thus conical shape of the material was formed.

Angle of repose was calculated by using the following expression [7].

$$
\emptyset=\tan -1 \frac{2\left(H_{a}-H_{b}\right)}{D_{b}} \ldots
$$

\section{Results and Discussion}

The result of physical property is shown below. The result of different physical properties of Kodo crop with the three moisture content of $7 \%, 11 \%$ and $12.6 \%$. On dry basis are presented in the following figure and regression equation.

\section{Length, width and thickness}

The result shows length, width and thickness of Kodo in variety JNk-101, JNk-364 and Niwas-1 increased with increase in moisture content from $7 \%$ to $12.6 \%$. the length, width and thickness of JNK-101 varied from 2.38 to $2.68 \mathrm{~mm}, 1.43$ to $2.00 \mathrm{~mm}$ and 1.01 to 1.34 $\mathrm{mm}$,

Similarly in JNK-364 LBT range from 2.27 to $2.72 \mathrm{~mm}, 1.34$ to $1.75 \mathrm{~mm}$ and 0.96 to 1.30 $\mathrm{mm}$ with respect to moisture content similar trend observed in in Niwas-1 LBT range from 2.44 to $2.95 \mathrm{~mm}, 1.78$ to $2.32 \mathrm{~mm}$ and 1.32 to $1.70 \mathrm{~mm}$. This happened when the moisture increased grain length, width and thickness increased because increased upon swelling which turns in increased in LBT. As shown in fig. 1, fig.2, fig. 3and required regression equation is shown in table 1 .

\section{Size}

The size of Kodo with three variety JNK-101, JNk-364 and Niwas-1 increased with increase in moisture $7 \%$ to $12.6 \%$ the size of JNK-101 varied from 1.49 to $1.91 \mathrm{~mm}$ wherein variety JNK-364 the size varied from 1.43 to 1.82 $\mathrm{mm}$ and similarly in Niwas- 1 the size varied from 1.76 to $2.24 \mathrm{~mm}$. The result shows that the size of Kodo increased with increase in moisture content. 
Table.1 Correlation between length, width and thickness

\begin{tabular}{|l|l|l|l|}
\hline Parameters & Kodo JNK-101 & Kodo JNK-364 & Kodoniwas -1 \\
\hline Length & $0.15 \mathrm{x}+2.266$ & $0.175 \mathrm{x}+2.23$ & $0.255 \mathrm{x}+2.19$ \\
& $\mathrm{R}^{2}=0.848$ & $\mathrm{R}^{2}=0.892$ & $\mathrm{R}^{2}=0.998$ \\
\hline Width & $0.285 \mathrm{x}+1.186$ & $0.205 \mathrm{x}+1.176$ & $\mathrm{y}=0.27 \mathrm{x}+1.466$ \\
& $\mathrm{R}^{2}=0.939$ & $\mathrm{R}^{2}=0.889$ & $\mathrm{R}^{2}=0.928$ \\
\hline Thickness & $0.165 \mathrm{x}+0.876$ & $0.17 \mathrm{x}+0.813$ & $0.19 \mathrm{x}+1.086$ \\
& $\mathrm{R}^{2}=0.900$ & $\mathrm{R}^{2}=0.946$ & $\mathrm{R}^{2}=0.865$ \\
& & & \\
\hline
\end{tabular}

Table.2 Regression equation between Sphericity and moisture content

\begin{tabular}{|c|c|c|}
\hline For Kodo JNK-101 & $\mathbf{y}=\mathbf{0 . 0 4 5} \mathbf{x}+\mathbf{0 . 5 9}$ & $\mathbf{R}^{2}=\mathbf{0 . 9 6 4}$ \\
\hline For Kodo JNK-364 & $\mathrm{y}=0.03 \mathrm{x}+0.583$ & $\mathrm{R}^{2}=0.964$ \\
\hline For Kodo Niwas-1 & $\mathrm{y}=0.03 \mathrm{x}+0.583$ & $\mathrm{R}^{2}=0.964$ \\
\hline
\end{tabular}

Table.3 ANOVA

\begin{tabular}{|c|r|r|r|r|r|r|}
\hline ANOVA & & & & & & \\
\hline $\begin{array}{c}\text { Source of } \\
\text { Variation }\end{array}$ & $S S$ & $d f$ & $M S$ & $F$ & P-value & F crit \\
\hline $\begin{array}{c}\text { Between } \\
\text { Groups }\end{array}$ & 137.5691 & 2 & 68.78454 & 11.37221 & 0.009095 & 5.143253 \\
\hline $\begin{array}{c}\text { Within } \\
\text { Groups }\end{array}$ & 36.29087 & 6 & 6.048478 & & & \\
\hline Total & 173.86 & 8 & & & & \\
\hline
\end{tabular}

Table.4 Correlation between bulk density, true density and porosity

\begin{tabular}{|c|c|c|c|}
\hline Parameters & Kodo JNK-101 & Kodo JNK-364 & Kodoniwas -1 \\
\hline Bulk & $\mathrm{y}=-2.165 \mathrm{x}+682.5$ & $\mathrm{y}=-5 \mathrm{x}+689.0$ & $\mathrm{y}=-7.2 \mathrm{x}+694.1$ \\
\hline density & $\mathrm{R}^{2}=0.806$ & $\mathrm{R}^{2}=0.990$ & $\mathrm{R}^{2}=0.957$ \\
\hline True & $\mathrm{y}=-12.91 \mathrm{x}+1245$. & $\mathrm{y}=-13.73 \mathrm{x}+1244$. & $\mathrm{y}=-12.45 \mathrm{x}+1243$ \\
\hline density & $\mathrm{R}^{2}=0.764$ & $\mathrm{R}^{2}=0.950$ & $\mathrm{R}^{2}=0.850$ \\
\hline Porosity & $\mathrm{y}=-0.415 \mathrm{x}+45.08$ & $\mathrm{y}=-0.22 \mathrm{x}+44.57$ & $\mathrm{y}=-0.145 \mathrm{x}+44.29$ \\
& $\mathrm{R}^{2}=0.864$ & $\mathrm{R}^{2}=0.909$ & $\mathrm{R}^{2}=0.968$ \\
\hline
\end{tabular}


Fig.1 Effect of moisture content on Length, width and thickness in Kodo JNK-101

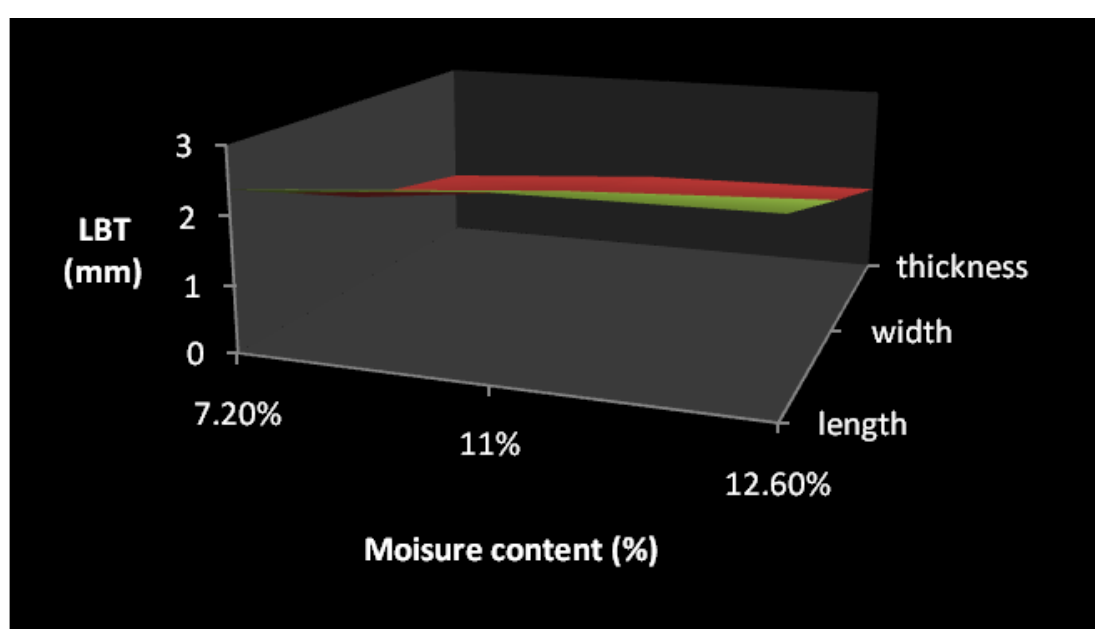

Fig.2 Effect of moisture content on Length, width and thickness in Kodo JNK-364

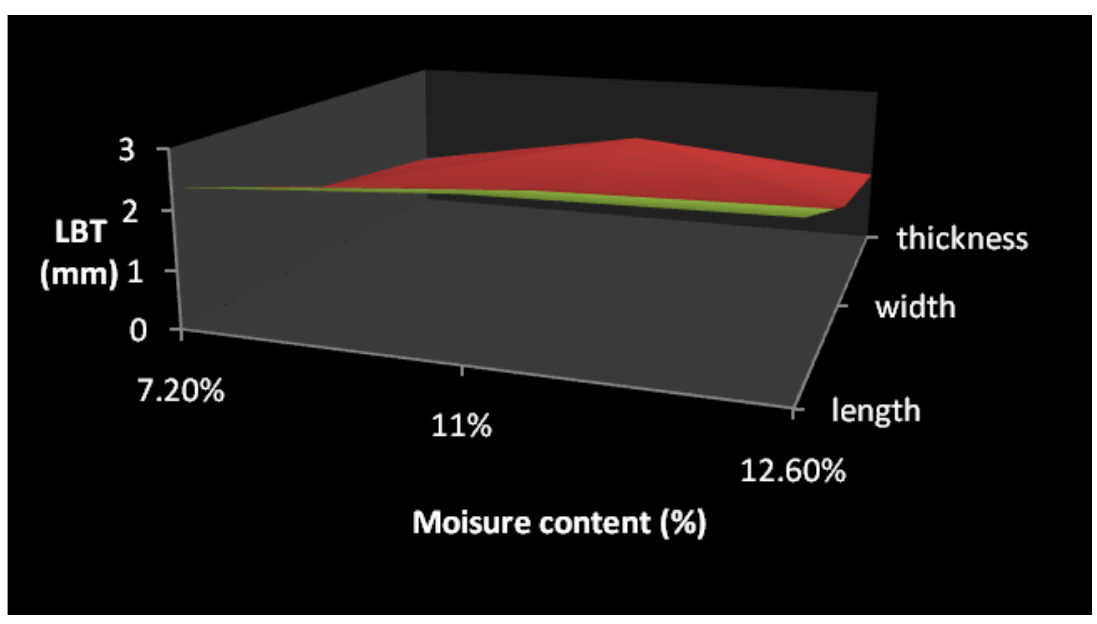

Fig.3 Effect of moisture content on Length, width and thickness in Kodo Niwas-1

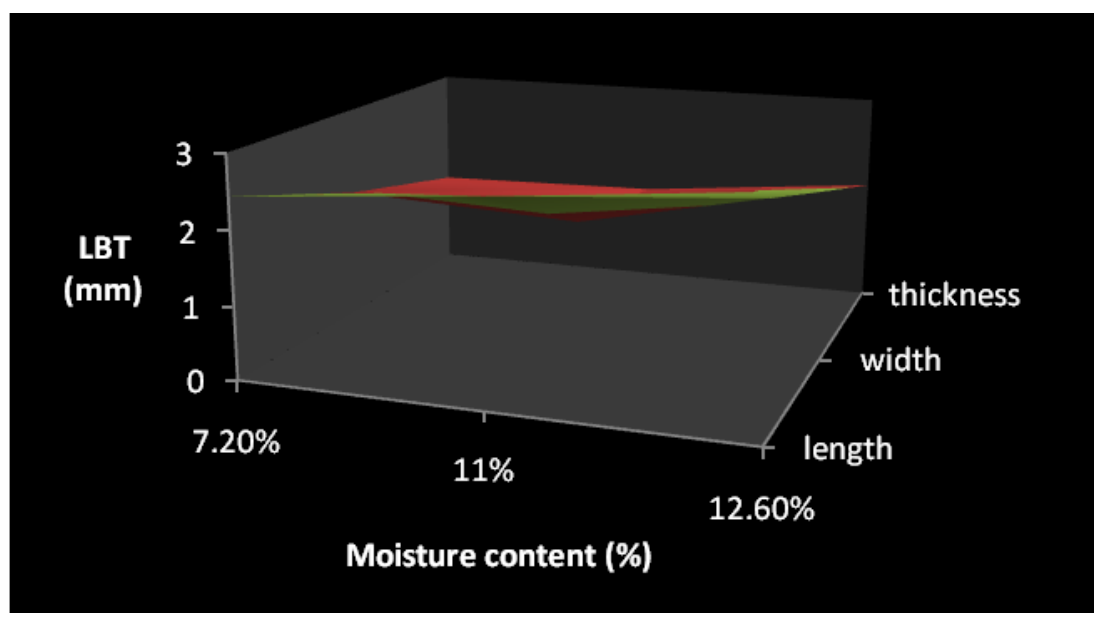


Fig.4 Effect of moisture content on sphericity in Kodo JNK-101, JNK-364, Niwas-1

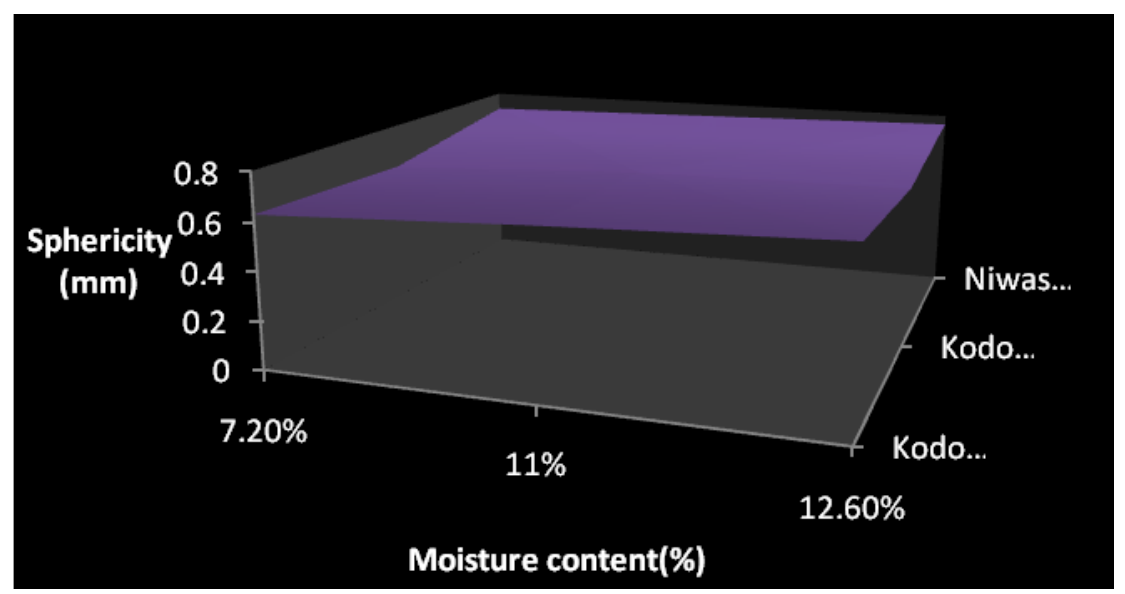

Fig.5 Effect of moisture content on Bulk density in Kodo JNK-101, JNK-364, Niwas-1

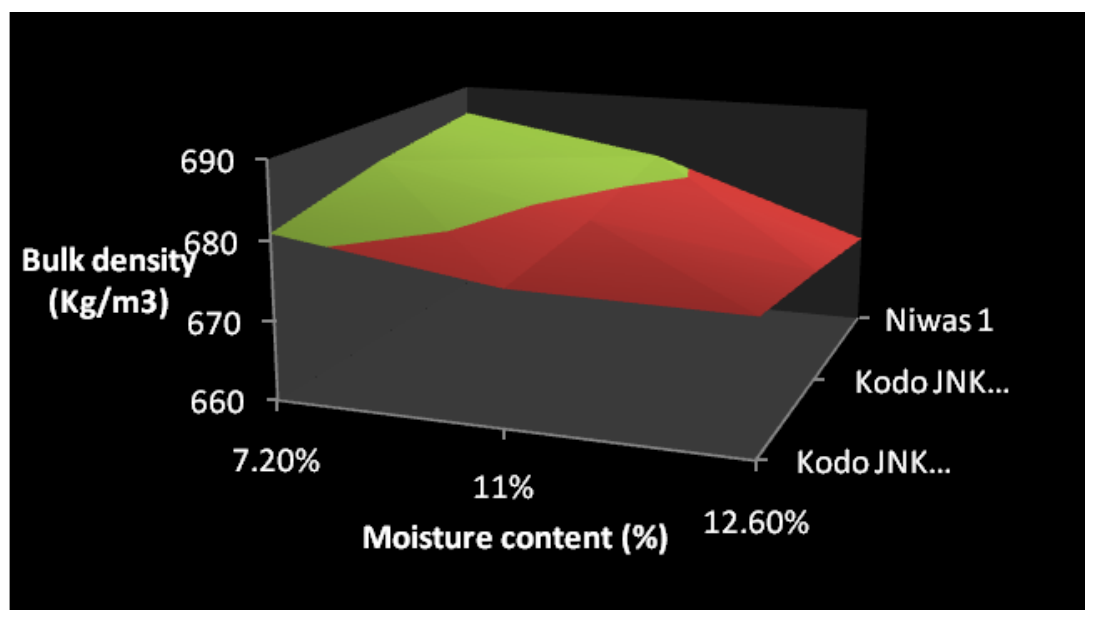

Fig.6 Effect of moisture content on True density in Kodo JNK-101, JNK-364, Niwas-1

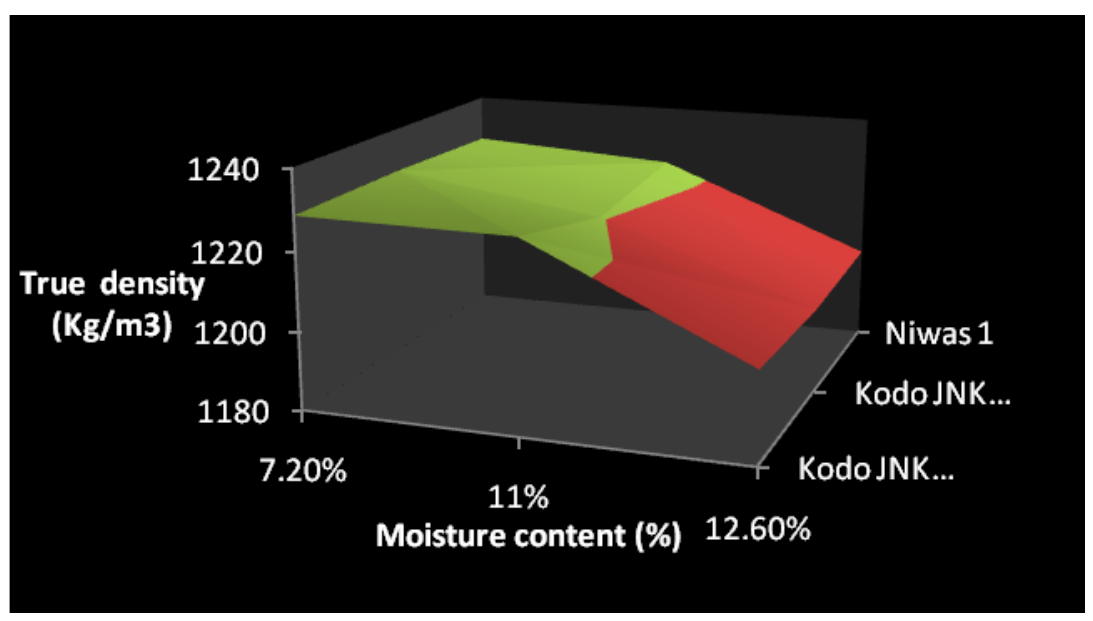


Fig.7 Effect of moisture content on Porosity in Kodo JNK-101, JNK-364, Niwas-1

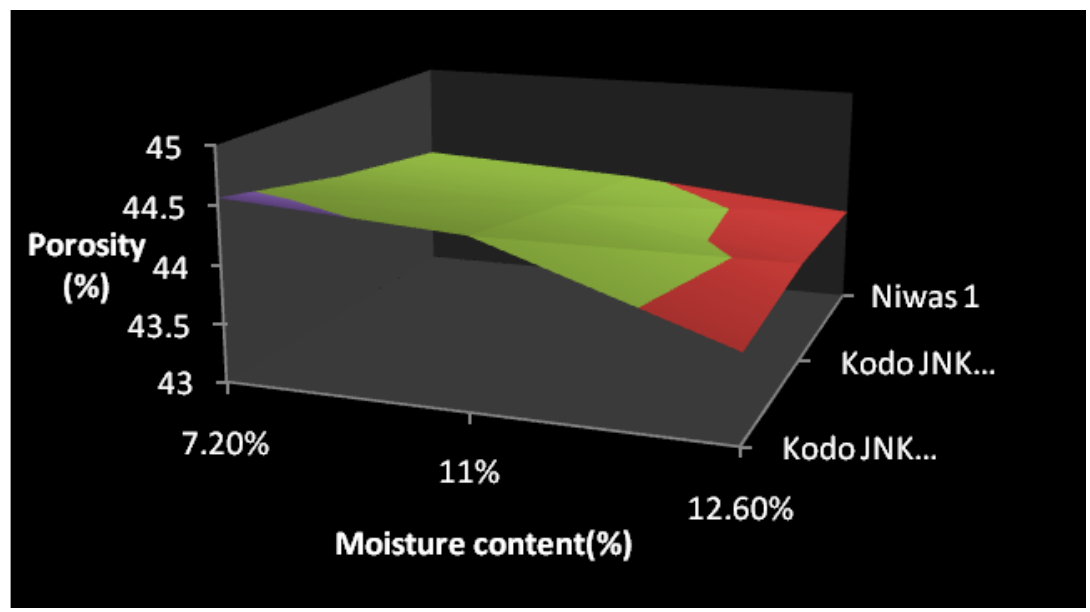

Fig.8 Effect of moisture content on Angle of repose in Kodo JNK-101, JNK-364, Niwas-1

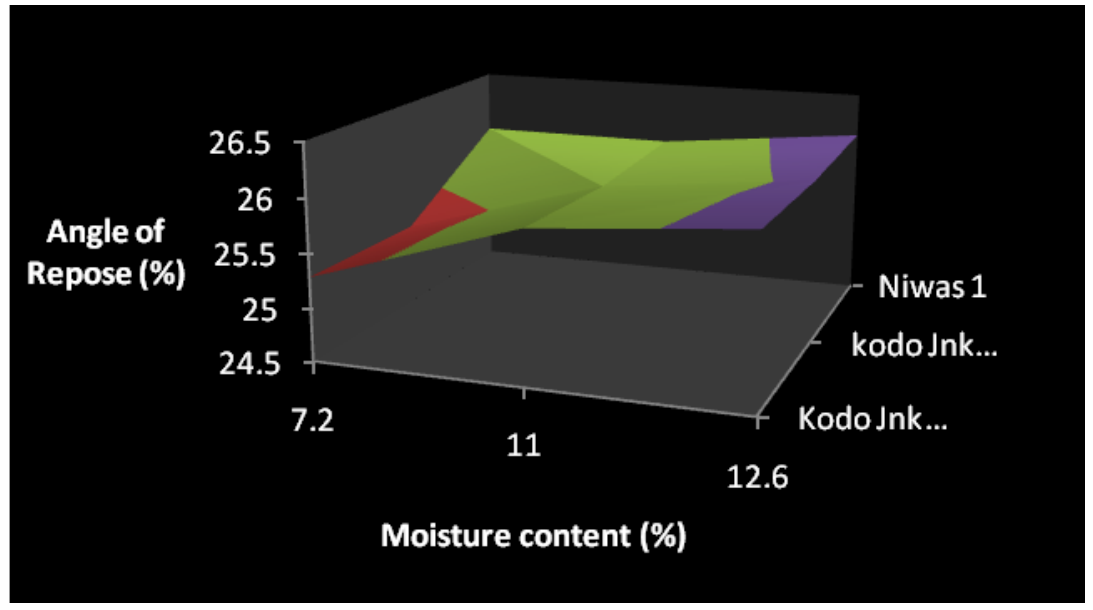

\section{Sphericity}

The sphericity of Kodo increases with variety JNK-101 increase from 0.63 to $0.72(\mathrm{~mm})$ as the moisture content increased from 7.10 to $12.6 \%(\mathrm{db})$. Similarly in JNK-364 and Niwas-1 the sphericity increased from 0.61 to 0.67 and 0.72 to $0.76(\mathrm{~mm})$. There is little variation at $11 \%$ moisture content in Niwas-1 due to the effect of variety and moisture content. The result is shown in fig. 4 and the relationship between sphericity and moisture in following table no.2.

\section{Bulk density, true density and porosity}

The bulk density, true density and porosity for Kodo millet obtained at three different moisture content ranging from $7 \%$ to $12.6 \%$ (db). The bulk density, true density and porosity decreased in JNK-101from 681 to $667.67 \mathrm{~kg} / \mathrm{m}^{3}, 1228.50$ to $1202.67 \mathrm{~kg} / \mathrm{m}^{3}$ and 44.57 to $43.74 \%$. Similarly in variety JNK364 the bulk density, true density and porosity increased with respect to moisture content from 684.33 to $674.33 \mathrm{~kg} / \mathrm{m}^{3}, 1228.80$ to $1201.33 \mathrm{~kg} / \mathrm{m}^{3}$ and 44.31 to $43.87 \%$. this trend also followed in Niwas-1 the bulk density, true density and porosity varied from 686.07 to $671.67 \mathrm{~kg} / \mathrm{m}^{3}, 1227.90$ to 1203 $\mathrm{kg} / \mathrm{m}^{3}$ and 44.13 to $43.84 \%$ respectively. The result is shown in fig. 5,6,7 and the equation is shown in table no.4 The ANOVA table no.3shows that the result is significant. 


\section{Angle of repose}

The angle of repose at different moisture content range from 7 to $12.6 \%(\mathrm{db})$ increased with increase in moisture content shown and fig.8. The angle of repose increased in JNK101 ranged from 25.28 to 26.07 wherein variety JNK-364 the angle of repose 25.26 to 26.04 and in Niwas-1angle of repose varied from 25.39 to 26.07. The relationship between the angle of repose and moisture content as shown in fig 8 .

In conclusion, it was observed that the length, width and thickness of Kodo with all three variety JNK-101, JNK-364 and Niwas -1 increased with increasing moisture content. Also observed that the size, sphericity increased as the moisture content increases. The value of bulk density, true density and porosity decreased as the moisture content increases. The angle of repose with all three variety increases with increase in moisture content.

\section{Acknowledgement}

The author is thankful to CSIR (Council of Scientific \& Industrial Research) New Delhi, for providing valuable monetary support for the research work.

\section{References}

Hadimani, N.A., and Malleshi, N.G., 1993, Studies on milling, Physico-chemical properties, nutrient composition and dietary fibre content of millets. $J$. Food Sci. andTech., 30: 45-52.

Itagi, S., (2003), Development and evaluation of millet-based composite food for type II diabetics. Ph. D., Thesis, University of Agricultural Sciences, Dharwar.

Kulkarni, L.R., Naik, R.K. and Katarki, P.A, (1992), Chemical composition of minor millets.Karnataka J. Agric. Sci., 5 (3): 255-258.

Kumar D., Patel S., Naik R.K., Mishra N. K. (2016) Study on Physical Properties of Indira Kodo-I (Paspalum Scrobiculatum L.) Millet. International Journal of Engineering Research \& Technology (IJERT) 5(1):39-45.

Mohsenin, N.N. (1986). Physical Properties of Plant and Animal Materials, 2nd edition. Gordon and Breach Science Publishers, New York

Source - www.indiastate.com, 2015.

\section{How to cite this article:}

Shalini Chaturvedi, Atul Kumar Shrivastava, R. Shiv Ramakrishnan, Ganesh Kumar Koutu and Sanjay Singh. 2020. Effect of Moisture Content on Some Physical properties of three varieties of Kodo (Paspalum scrobiculatum L.) Millet. Int.J.Curr.Microbiol.App.Sci. 9(09): 3781-3788. doi: https://doi.org/10.20546/ijcmas.2020.908.436 